DOI https://doi.org/10.18551/rjoas.2018-06.35

\title{
EFFECT OF ENTREPRENEURSHIP TRAINING TOWARDS ENTREPRENEURSHIP BEHAVIOR, BUSINESS MOTIVATION AND ENTREPRENEURSHIP ORIENTATION
}

\author{
Kartikaningrum Lina \\ Magister Program, Faculty of Administrative Science, University of Brawijaya, Indonesia \\ Prasetya Arik, Mawardi Muhammad Kholid \\ Faculty of Administrative Science, University of Brawijaya, Indonesia \\ *E-mail: lina.kartikaningrum13@gmail.com
}

\begin{abstract}
This study aims to determine the effect of entrepreneurship training, entrepreneurship behavior, and business motivation towards entrepreneurship orientation in SMEs which became members of SMEs Training Center in Indonesia. This research was conducted with paradigm of quantitative research method, with sample amounted to 73 participants of SME training. The results of the study explain that all the relationships developed in this study have a significant effect. One of them is entrepreneurship training that has a significant effect on entrepreneurship orientation. The theoretical and practical benefits in this study emphasize on the study of entrepreneurship training of SMEs in developing countries important for continuous research.
\end{abstract}

\section{KEY WORDS}

SMEs, entrepreneurship training, entrepreneurship behavior, business motivation, entrepreneurship orientation.

Indonesia as one of the developing countries in a world with the fourth largest population. (BPS, 2016) has a wide variety of human resource characteristics that can be utilized to improve the economy. Through this large population, Indonesia becomes an attractive market for both domestic and foreign investors. With regard to domestic entrepreneurs, Small and Medium Enterprises (SMEs) act as one of the main economic in Indonesia (Tambunan, 2008). Small and Medium Enterprises (SMEs) always related to entrepreneurship. The actors of Small and Medium Enterprises (SMEs) in Indonesia has a wide range of innovations by the knowledge of the complex entrepreneurial as their background (Tambunan, 2008). That is has the phenomenon many actors of small business can achieve success even though they do not have a high education background related to entrepreneurship. In addition there are business actors who already have a high education background related to the business world has not achieved the desired success. Based on the phenomena that arise in entrepreneurship creates a new question, is entrepreneurship created or born? (Priyono and Muqorobin, 2015).

Newly entrepreneurs can be created through government programs so that more and more educated entrepreneurs with highly competitive can be created for economic progress of the country. Through a view that promotes Small and Medium Enterprises (SMEs) it is explained that the government plays an indirect and direct role for the development of Small and Medium Enterprises (SMEs) in Indonesia. The role can be indirectly through the development of infrastructure and also a good public servant, while the role can be directly through the program of business capital loans or training in terms of improving the quality of Small and Medium Enterprises (SMEs).

The importance of training for small businesses is expressed by Katerina et al., (2010) which states that training programs for entrepreneurs can broaden thinking about new ideas and insights that have been unthinkable. Entrepreneurship has a process that must be passed by Small and Medium Enterprises (SMEs). The process through various challenges and difficulties both from yourself and the factors of business competition. However, these 
processes can cultivate and train positive entrepreneurial behaviors and make an entrepreneur increasingly mature in the face of business challenges. Entrepreneurial behavior owned by an entrepreneur in fact it needs to be developed, for example by adding knowledge insight. The addition of knowledge and insight should be done gradually and continuously through the learning process. Kirkley (2016) states that sometimes every learning process is not recognized as a tool in developing entrepreneurial behavior, since it is usually considered a part of the experience. The process of learning about entrepreneurship is a way that can grow business motivation.

Sanches et al., (2013) states that entrepreneurial behavior continues to grow, capable of becoming a personal motivation to achieve better goals in entrepreneurship. Business motivation is a stimulus either from themselves or outside environment to encourage someone in behaving related to entrepreneurship. Hytti et al., (2013) states that the motivation to be an entrepreneur can be formed with the pattern of entrepreneurial education systematically and measurable in the process. In addition, according to Azwar (2000) motivation is a form of stimulation obtained due to environmental conditions, groups, and individuals who personally affect the thinking in it to do something with more spirit.

High motivation in essence will increase enthusiasm for business actors to continue to focus on entrepreneurship or entrepreneurship oriented. When creating new or existing business activities, entrepreneurs have at least an entrepreneurial orientation such as a desire to achieve goals, take risks, and be able to take advantage of new ideas integrated with the use of their resources, and personal imagination to make a difference not only make business as a way to survive everyday but also able to grow better and able to reach a wider market for the economic improvement of business actors.

The explanation of the variables discussed in the previous research is known to be a research gap, such as research with the importance of training for small and medium enterprises (SMEs) in Indonesia which is still rare (Tambunan, 2008), especially on the role of government in the development of Small and Medium Enterprises (SME). While studies with the theme of entrepreneurship training that emphasizes the role of government have been done in developed countries such as Audet and Couteret (2012) in Canada and Katerina et al., (2010) in Sweden. So the gap of this research to enrich the discussion of the development of Small and Medium Enterprises (SMEs) in developing countries such as Indonesia, especially the role of government in it.

\section{LITERATURE REVIEW}

Entrepreneurship training according to Bolton and Lane (2014) is the process of shaping the mindset, attitude, and behavior of being a true entrepreneur thus directing the decision to be an entrepreneurship as a career choice. Good entrepreneurship training will be able to stimulate someone to direct the focus on entrepreneurship deeper. The intended focus in this regard is that training will shape entrepreneurial behaviors that may not have been utilized in terms of enhancing entrepreneurial skills. Clarke and Sweet (2004) argue that entrepreneurship training can encourage a person to want to know more about entrepreneurial science that can shape entrepreneurial behavior and can become a positive routine for the future. In addition, Hytti et al., (2010) also states that entrepreneurial behavior can be grown through training media or experiences that have been owned by individuals so far. So the relationship between entrepreneurship training and behavior is a good causal relationship for business actors. Based on the relationship described, the proposed research hypothesis is: Behavior.

Hypothesis 1: There is a relationship of Entrepreneurship Training to Entrepreneurship

Character of small business actors have diverse differences, the difference is a natural thing that is owned because a lot of factors that influence it. Heinonen et al., (2010) states that entrepreneurial learning or training is aimed at shaping the skills, insights, ways of business development and for improving business performance. In the process through which the training is one of the main objectives is to motivate business actors to start a new 
business or to improve the quality of the business that has been running. Collete et al. (2005) states that to stimulate intrinsic and extrinsic factors of business actors can be done through broad suggestions and insights that are packaged in the form of entrepreneurship training. Therefore entrepreneurship training is one of the right tools to stimulate or motivate small and medium enterprises actors (SMEs). Motivation.

Hypothesis 2: There is a relationship of Entrepreneurship Training to Business

Business Motivation is broadly divided into two main parts namely internal and motivation from external influences. Seinonen et al., (2013) suggests that entrepreneurial behavior can influence the behavior of individuals in terms of intrinsic or extrinsic. Intrinsic factors can be formed through the unity of one goal and from the process of growing personal motivation to do something more eagerly. In addition, Kirkley (2016) states that extrinsic factors can be influenced by environmental factors that together have the same goal so that the positive motivation to achieve the vision and mission are applied, this can be done on motivation to entrepreneurship. Factors The entrepreneurial behavior associated with business motivation is based on the study of Eijdenberg et al. (2016) theory which states that there is an influence of entrepreneurial behavior on one's stimulation to be more motivated in running a business. Motivation.

Hypothesis 3: There is a relationship of Entrepreneurship Behavior to Business

Entrepreneurship training is established with the aim of helping to direct small and medium business actors (SMEs) to be entrepreneurial oriented. Audet and Couteret (2012) states that the effectiveness of entrepreneurship training will appear when small and medium business actors (SMEs) know the market conditions and how appropriate strategies are in responding. In the past, small and medium enterprises (SMEs) do not have clear direction and objectives related to their business, training as a solution to guide clear and specific objectives and that can be measured through innovative, pro-active and risk-taking attitude. The entrepreneurship orientation can be initiated through the process of managing the creativity and innovation of small business owned by small and medium enterprises (SMEs) by adjusting to market needs. This is in accordance with the opinion of Katerina et al., (2010) which states that Small and Medium Enterprises (SMEs) have a high level of innovation then directing according to market needs is a solution to improve the quality of Small and Medium Enterprises (SMEs).

Hypothesis 4: There is a relationship of Entrepreneurship Training to the Entrepreneurship Orientation.

Entrepreneurial behavior is the process of finding self-identity in the business world, and is able to benefit many people through positive behavior. The relationship of entrepreneurial behavior and entrepreneurial orientation has been an inseparable relationship. This is in accordance with the opinion of Seinonen et al., 2013 which says that entrepreneurial behavior is one important part in improving the orientation of entrepreneurship. Entrepreneurial behavior becomes the basis of someone who has a common goal to improve the quality of life through the formation of a competitive business. Sanches and Sahuquillo (2013) states that entrepreneurial behavior can improve relationships or positive relationships and then these relationships can be utilized to improve the focus at actors of small and medium enterprises (SMEs). Motivation.

Hypothesis 5: There is a relationship of Entrepreneurship Behavior to Business

The quality of a small and medium enterprises (SMEs) can be influenced by various factors, but the main influencing factor can be seen through the high spirit of business actors to succeed. The high spirit can be built through the level of motivation. Eijdenberg et al (2016) states that the actor's motivation of small and medium enterprises (SMEs) can reflect the quality of business achieved. Morris et al. (2016) states that the great motivation in starting a business is a great business opportunity and can be seen by small and medium business actors (SMEs) as a phenomenon that must be utilized. Business Motivation is able to provide direction to Small and Medium Enterprises (SMEs) to be more pro-active, risk-taking and 
innovative, all of which are context in entrepreneurship orientation. Based on these opportunities the business actor will mobilize all the expertise and thinking system that is in order to be able to take advantage of the existing situation.

Hypothesis 6: There is a relationship of Business Motivation to Enterpreneurship Orientation

\section{METHODS OF RESEARCH}

This research was conducted on the SME training participants through the government which was formed specifically as the development program of government at SMEs Training Center in East Java, Indonesia. Through simple random sampling technique, a sample of 73 SMEs. The research analysis used the path analysis. Then the measurement of variables developed from several previous studies, namely Entrepreneurship Training in measuring by seven items that adopted research from Katerina et al., (2010).

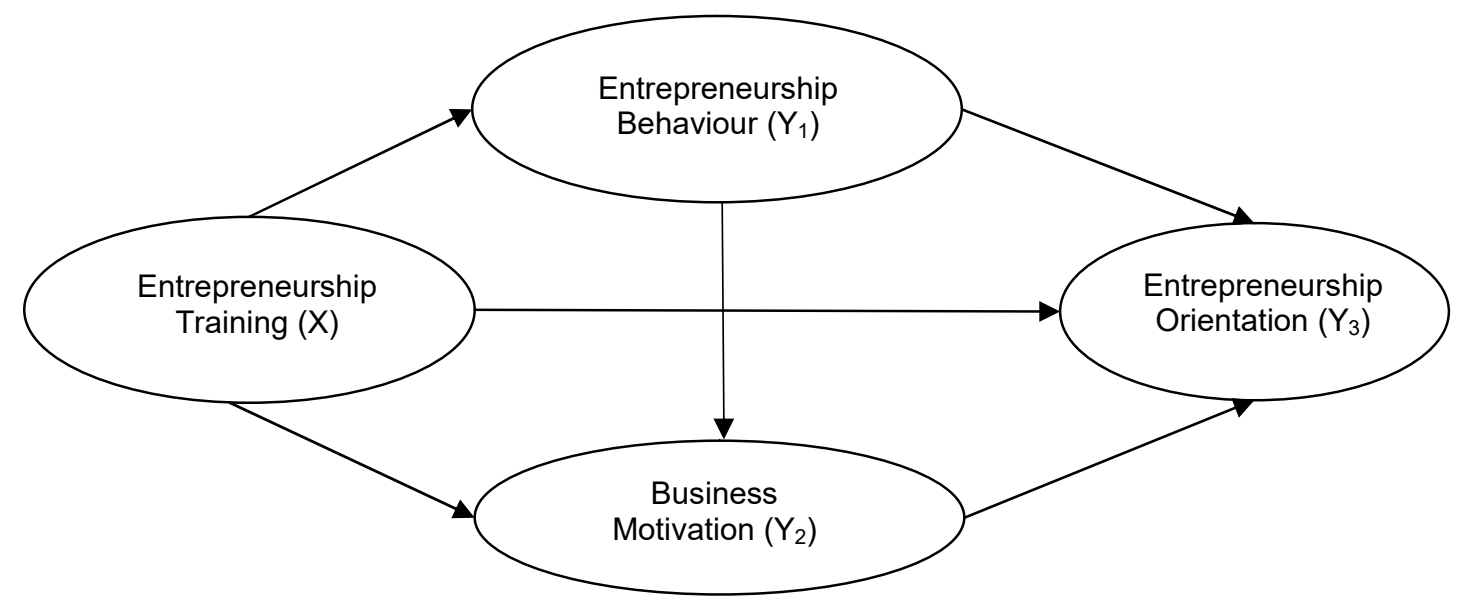

Figure 1 - Conceptual and Hypothesis Model

Entrepreneurial behavior refers to Seinonen and Sahuquillo (2013) and Kirkley (2016) studies with five items. While the business motivation was developed from the research findings Hytti et al., (2010), with six items. Finally the entrepreneurial orientation of this variable measurement adopts research from Wiklund (2007) and Narver and Slater (2000) which consists with six items. The conceptual model of the current study is described in the following Figure 1.

\section{RESULTS AND DISCUSSION}

The direct influence of Entrepreneurship training on entrepreneurial behavior is in line with research results from Katerina et al. (2010) which states that entrepreneurship training has a positive effect on entrepreneurial behavior. While in this research the beta coefficient of 0.394 shows that the effect of Entrepreneurship Training on Entrepreneurship Behavior, with $t$ count of 5.465 and probability of $0.000(p<0.05)$. The direction of a positive relationship indicates that the more often or better the entrepreneurship training will increase Entrepreneurship behavior. Katerina et al., (2010) in her research results stated that wellcrafted entrepreneurship training will be able to stimulate an individual to direct the focus on entrepreneurship deeper. The intended focus in this regard is that training will shape entrepreneurial behaviors that may not have been utilized in terms of enhancing entrepreneurial skills. Hence, Hypothesis 1 on the research is accepted and significant.

This study supports Audet and Couteret (2012) research which states entrepreneurship training is positively related to business motivation. The results of testing the influence of Entrepreneurship Training on Business Motivation show the beta coefficient of 0.319 indicates that the effect of Entrepreneurship Training on Business Motivation, $t$ count 3.241 
and probability of $0.002(p<0.05)$, then the decision is Hypothesis 0 rejected, so that Entrepreneurship Training has a significant effect on Business Motivation.

Table 1 - Recapitulation Path Analysis

\begin{tabular}{|c|c|c|c|c|}
\hline Relation of Variable & Standardized & t count & Probability & Information \\
\hline$X \rightarrow Y_{1}$ & 0.544 & 5.465 & 0.000 & Significant \\
\hline$X \rightarrow Y_{2}$ & 0.319 & 3.241 & 0.002 & Significant \\
\hline$Y_{1} \rightarrow Y_{2}$ & 0.499 & 5.073 & 0.000 & Significant \\
\hline$X \rightarrow Y_{3}$ & 0.360 & 3.813 & 0.000 & Significant \\
\hline$Y_{1} \rightarrow Y_{3}$ & 0.248 & 2.409 & 0.019 & Significant \\
\hline$Y_{2} \rightarrow Y_{3}$ & 0.313 & 2.920 & 0.005 & Significant \\
\hline$X \rightarrow Y_{1} \rightarrow Y_{3}$ & 0.135 & 2.027 & 0.021 & Significant \\
\hline$X \rightarrow Y_{2} \rightarrow Y_{3}$ & 0.100 & 2.287 & 0.011 & Significant \\
\hline
\end{tabular}

Source: Path Analysis.

Notes: $X=$ Entrepreneurial Training; $Y_{1}=$ Entrepreneurship Behavior; $Y_{2}=$ Business Motivation; $Y_{3}=$ Entrepreneurship Motivation.

The direction of a positive relationship indicates that with increasing entrepreneurship training it will further increase business motivation. Character of small business actors have diverse differences, the difference is a natural thing that is owned because a lot of factors that influence it. Heinonen et al., (2010) states that entrepreneurial learning or training is aimed at shaping the skills, insights, ways of business development and for improving business performance. In the process through which the training is one of the main objectives is to motivate business actors to start a new business or to improve the quality of the business that has been running. Then Hypothesis 2 in this research is accepted and significant.

This study also supports the research of Hytti et al., (2010) and Eijdenberg et al., (2016) which explains the positive relationship of entrepreneurial behavior to business motivation. The test result of Entrepreneurship Behavior on Business Motivation shows the beta coefficient of 0.499 indicates that the influence of Entrepreneurship Behavior on Business Motivation, with $t$ count 5.073 and probability of $0.000(p<0.05)$, then the decision is Hypothesis 0 rejected, so Entrepreneurship Behavior has a significant effect on Business Motivation. Therefore Hypothesis 3 in this study is accepted and significant.

This study is in line with the research of Seinonen et al., (2013) which explains there is a positive relationship between entrepreneurship training on entrepreneurship orientation. The results of testing the effect of Entrepreneurship Training on the Orientation of Entrepreneurship shows the beta coefficient of 0.360 indicates that the effect of Entrepreneurship Training on the Orientation of Entrepreneurship, with t count 3.813 and the probability $0.000(p<0.05)$, then the decision is Hypothesis 0 rejected, so Entrepreneurship Training significantly Orientation of Entrepreneurship. Entrepreneurship training is established with the aim of helping to guide SMEs to orient to entrepreneurship. Audet and Couteret (2012) states that the effectiveness of entrepreneurship training will be evident as small business actors know the market conditions and how appropriate strategies are in responding. So Hypothesis 4 in this study was accepted and significant.

Relating to entrepreneurial behavior has a positive effect on entrepreneurship orientation. This study supports the research conducted by Seinonen et al. (2013), Sanches and Sahuquillo (2013). The results of testing the influence of Entrepreneurship Behavior on Entrepreneurship Orientation show the beta coefficient 0.248 shows that the effect of Entrepreneurship Behavior on Entrepreneurship Orientation, with $t$ count 2.409 and probability $0.019(p<0.05)$, then the decision is Hypothesis 0 is rejected, so that Entrepreneurship Behavior influential and significant to Orientation of Entrepreneurship. The direction of a positive relationship indicates that the more entrepreneurial behavior increases, will result in a stronger orientation in doing business. The relationship of entrepreneurial behavior and entrepreneurial orientation has been an inseparable relationship. This is in accordance with opinion (Seinonen et al., 2013) entrepreneurial behavior is an important part 
in improving the orientation towards entrepreneurship. Entrepreneurial behavior becomes the basis of someone who has a common goal to improve the quality of life through the formation of a competitive business. So that the Hypothesis 5 in this study is accepted and significant.

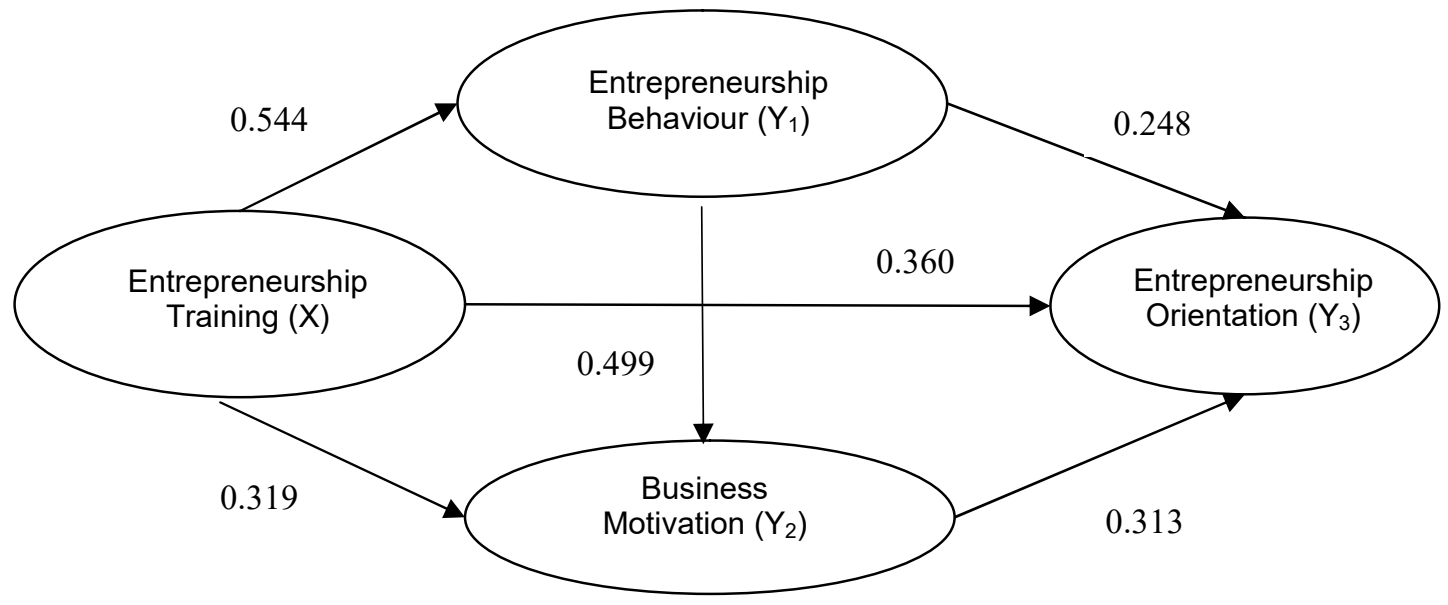

Figure 2 - Research Result

Source: Path Analysis

This research is in line with Eijdenberg et al., (2015) and Freese (2016) which states that business motivation affects entrepreneurship orientation. The result of examination of the influence of Business Motivation to the Entrepreneurship Orientation shows the beta coefficient 0.313 indicates that the influence of Business Motivation on the Entrepreneurship Orientation, with $t$ count 2.920 and the probability $0.005(p<0.05)$, then the decision is Hypothesis 0 rejected, so that Business Motivation significantly Orientation of Entrepreneurship. The quality of a UMKM can be influenced by various factors, but the main influencing factor can be seen through the high spirit of business actors to succeed. The high spirit can be built through the level of motivation built. Business Motivation are able to direct small business actors to be more pro-active, risk-taking and innovative, all of which are contextual in the entrepreneurial orientation. So that Hypothesis 6 in this study is accepted and significant.

\section{CONCLUTION}

Research that conducted on training participants and the development of SMEs in Indonesia explains that SMEs become the main pillar of Indonesian economy as a developing country is very big benefits. The entrepreneurship training established in the government program has a significant effect on improving entrepreneurial behavior, increasing business motivation, and also being able to bring UMKM to orient to entrepreneurship. However, this study has some limitations as research is conducted only in one province in Indonesia, so it is expected that further research can conduct research on other areas more broadly to improve reference on the topic of entrepreneurship training in UMKM in Indonesia.

\section{REFERENCES}

1. Audit. Josee and Couteret. Paul. 2012. Coaching the Entrepreneur: Features and Success Factors. Journal of Small Business and Entreprise Development. Emeraldlnsight. Vol. 19, Issue; 3.

2. Arikunto. 2007. Metode Penelitian Kuantitatif. Jakarta: Salemba Empat.

3. Bozovic, Stamenovic, R. (2007), Cultural Perspective Of Wayfinding Behavior-Exploring The Socio Spatial Variable in Three Chinese Hospitals Case Studies, International Journal of Architecture Research. 
4. Coleman, J.S. 1990, Social Capital in the Creation of Human Capital, American Journal of Sociology, 94, Supplement. S95-S120.

5. Cooper, J.R. 1993. A Multidimensional Approach to the Adoption of Innovation. Management Decision. Pp 493-502.

6. Darpujianto. 2014. Pengaruh Pembelajaran Kewirausahaan terhadap Motivasi Berwirausaha pada Mahasiswa STIE dan STMIK ASIA MALANG. Jurnal JIBEKA. Vol 8. No 1.

7. Eijdenberg. Emiel L, Pass. Leonard J, and Masurel. Enno. 2015. Entrepreneurial Motivation and Small Business Growth in Rwanda. Journal of Entrepreneurship in Emerging Economies. Emeraldlnsight. Vol. 7. Issue; 3.pp 212-340.

8. Eijdenberg. Emiel L. 2016. Does One Size Fit All? A Look at Entrepreneurial Motivation and Entrepreneurial Orientation in The informal Economy of Tanzania. Journal Entrepreneurial Behavior \& Research. EmeraldInsight. Vol. 22. Issue 6. Pp 804-834.

9. Frese. Michael, Lydia Hass, and Friedrich. Christian. 2016. Personal Initiative Training for Small Business Owners. ScienceDirect. Vol. 5. Issue 8. Pp 27-36.

10. Hakim. Supriadi. 2003. Kewirausahaan sebagai solusi kreatif. Jakarta; Salemba Empat.

11. Hasbullah, Jousairi. 2006. Sosial Capital (Menuju Keunggulan Budaya Manusia Indonesia). MR United Press: Jakarta.

12. Hubeis, Musa. 2009. Prospek Usaha Kecil Dalam Wadah Inkubator Bisnis. Jakarta: Ghalia Indonesia.

13. Hytti. Ulla, Stenholm. Pekka, Heinonen. Jarna, Seikkula. Jana. \& Leino. 2010. Perceived Learning Outcomes in Entrepreneurship Education. Education+Training Journal. Emeraldlnsight. Vol. 52, Issue; 8/9. Pp 587-606.

14. Indriartiningtias, Retno. 2009. Manajemen Industri Kecil Modern. Surabaya: Trunojoyo Pers.

15. Katerina. K. Sarri, Bakourus. Loannis L, Petridou. Eugenia. 2010. Entrepreneur Training for Creativity and Innovation. Journal of European Industrial Training. Emeraldlnsight. Vol. 34, Issue; 3. Pp 270-288.

16. Kirkley. Wiliam Walton. 2016. Entrepreneurial Behavior: the Role of Values. Journal Entrepreneurial Behavior \& Research. EmeraldInsight. Vol. 22. Issue 3. Pp 290-328.

17. Lestari, Retno Budi dan Wijaya, Trisnadi. 2012. Pengaruh Pendidikan Kewirausahaan terhadap Minat Berwirausaha Mahasiswa di STIE MDP, STMIK MDP, dan STIE MUSI. Jurnal IImiah STIE MDP. Vol. 1, No. 2.

18. Lumpkin, G.T and Dess G.G. 1996. Clarifying the Enterpreneurial Orientation Construct and Linking it to Performance. Academy of Management Review, Volume. 21 (1), p. 135172

19. Nazir, Mohammad. 2005. Metode Penelitian. Jakarta: Ghalia Indonesia.

20. Narver, J.C, Slater, S.F. and Maclachlan. D.L. 2004. Responsive and Proactive Market Orientation and New-Product Success. The Journal of Product Innovation Management. p. 334-347.

21. Narver, J.C and Slater, S.F. 2010. The effect of Market Orientation on Product Innovation. Journal of Marketing. P. 20-35.

22. Priyono, Edi dan Muqorobin, Agus. 2015. Studi Literatur Terkait Perilaku Kewirausahaan. Universitas Muhammadiyah Surakarta jurnal-Solo.

23. Putnam, R. D. 1993. The Prosperous Community : Social Capital and Public Life. The American of Prospect, 13, 35-42.

24. Saiman, Leonardus. 2009. Kewirausahaan: Teori, Praktik, dan Kasus-kasus. Jakarta. Salemba Empat.

25. Sanches. Virginia Barba and Sahuquillo. Carlos Atienza. 2013. Entrepreneurial Behavior: Impact of Motivation Factors on Decision to Create a New Venture. ScienceDirect. Vol.18. Issue 9, pp 132-138.

26. Sarwono, Jonathan. 2007. Analisis Jalur untuk Riset Bisnis dengan SPSS. Yogyakarta: Andi Offset.

27. Schumpeter, J., 1934. The theory of economic development. England. 
28. Sekaran, Uma, 2006. Metode Penelitian untuk Bisnis, Edisi Keempat, Jakarta; Salemba Empat.

29. Slater. Stanley F and Narver. John C. 2000. The Positive Effect of a Market Orientation on Business Profitability: A Balanced Replication. Journal of Business Research Vol. 48 Issue 8. Pp 69-73.

30. Soininen. Juha sakari, Puumailainen. Kaisu, and Durst. Susanne. 2013. Entrepreneurial Orientation in Small Firms-Values-Attitudes-Behavior Approach. Journal Entrepreneur Behavior\&Research. EmeraldInsight.Vol 19. Issue 6. pp 611-632.

31. Sumarsono, Sonny. 2010. Kewirausahaan. Graha IImu; Yogyakarta.

32. Sumartono. 2013. Pengantar Kewirausahaan. Jakarta; Salemba Empat.

33. Sunartiningsih, Agnes. 2004. Pemberdayaan Masyarakat Desa Melalui Institusi Lokal. Aditya Media;Yogyakarta.

34. Singarimbun, M. dan Efendi S. 1998. Metode Penelitian Survei. Jakarta: LP3ES.

35. Supryanto. 2012. Ekonomi Kewirausahaan. Jakarta; Salemba Empat.

36. Suriatna, D. 2013. Analisa Modal Sosial dan Inovasi Produk pada Pengusaha Mikro dan Kecil di Jawa Timur. Agora, 1(3), 1492-1503.

37. Tambunan, Tulus, 2002. Usaha Kecil dan Menengah di Indonesia: Beberapa Isu Penting, Penerbit Salemba Empat, Jakarta.

38. Tambunan, Tulus, 2008, SMEs Development In Indonesia: Do Economic Growth And Government Support Matter?. IJAPS. Volume 4, No.2.

39. Wang, Clement K. and Wong, Poh-Kam. 2004. Entrepreneurial Interest of University Students in Singapore.

40. Wiklund, Johan. 2007. Entrepreneurial Orientation, Risk Taking, and Performance in Family Firms. Family Business Review. Volume. XX, No.1. 